\title{
PERBINCANGAN DI MEDIA SOSIAL FILM PENDEK TILIK SEBAGAI HASIL DARI STRATEGI DIGITAL
}

\section{[Organic Discussion on Social Media About “TILIK” as a Result of Digital Strategy]}

\author{
Panji Nandiasa Ananda Mukadis ${ }^{1)}$ \\ ${ }^{1)}$ Program Studi Bisnis Digital, Universitas Bunda Mulia \\ Diterima 09-09-2020 / Disetujui 31-05-2021
}

\begin{abstract}
An Indonesian short film produced massive conversations like the film Tilik which is rarely found in our daily lives.A film directed by Wahyu Agung Prasetio and produced by Ravacana Films, a community-based production house in Yogyakarta had gained two million views on YouTube per 21 August 2020. The first day it was uploaded 17 August 2020, it had gained many tractions until around $30 \mathrm{~K}$ views, and then different kind of reactions multiply the number of viewers and conversation that also attract coverages from national media, online, offline, and also chose to be content for several television program, some coverage that is so pricey if we talk about Public Relations (PR) Value aspect.. The phenomena of Tilik is not for coming without reason, it came from some specific situation and then supported with good product material, and digital strategy. Talking about the number of its views we cannot cease to discuss the social condition around the society at that time. As a film, we cannot ignore the context of Tilik, context that had given it enough resource to gain traction from relevant people and communities. Context that had also gave it enough conversation materials the first days it was published on YouTube.
\end{abstract}

Keywords: Short Film, Youtube, Social Media, Viral Content, Digital Marketing

\begin{abstract}
ABSTRAK
Tidak setiap saat bisa kita temukan sebuah film pendek Indonesia menghasilkan perbincangan yang masif seperti film Tilik. Film pendek karya dari sutradara Wahyu Agung Prasetyo dan diproduki oleh Ravacana Films, sebuah rumah produksi berbasis komunitas di Yogyakarta memperoleh dua juta views di Youtube per 21 Agustus 2020. Awal diunggah sejak 17 Agustus 2020 film Tilik telah menarik banyak penonton hingga menghasilkan puluhan ribu views. Setelah beberapa hari jumlah views meningkat berkali lipat usai mendapat beragam reaksi dan akhirnya menghasilkan views beratus kali lipat, juga perbincangan yang terus berdengung di media sosial. Perbincangan yang terus bergulir mengenai Tilik kemudian menghasilkan peliputan lanjutan di media daring, cetak, maupun liputan di televisi yang tidak main-main nilainya bila dihitung secara nilai Public Relations (PR Value). Apa yang terjadi pada Tilik bukan lahir begitu saja melainkan hasil hasil dari strategi digital dan didasari teknis yang memadai serta pilihan-pilihan dalam alur cerita yang membuatnya menjadi bahan perbincangan di media sosial. Bicara tentang jumlah views dan perbincangan seputar film Tilik kita juga perlu memperhatikan kondisi sosial masyarakat saat film ini beredar secara daring Tidak lupa sebagai sebuah film, Tilik juga harus dilihat konteks yang dibawa, konteks yang memberinya bekal yang cukup untuk menanamkan menghasilkan traksi pada awal dan berbagai modal untuk jadi bahan perbincangan hari-hari pertama sejak film ini ditayangkan di Youtube.
\end{abstract}

Kata Kunci: Film Pendek, Youtube, Media Sosial, Konten Viral, Pemasaran Digital

\section{PENDAHULUAN}

Per 17 Agustus 2020 sebuah film pendek berjudul Tilik kaya sutradara Wahyu Agung Prasetyo mulai tayang di platform
Youtube sejak 21 Agustus 2020 mendapat lebih dari dua juta views dengan terlebih dahulu memperoleh perbincangan dengan jumlah yang signifikan di media sosial

\footnotetext{
*Korespondensi Penulis:

E-mail: L1858@ @ecturer.ubm.ac.id
} 
sehingga beberapa kata kunci terkait film ini menjadi trending topik selama beberapa hari.

Perbincangan di media sosial ini terus mengalir atas konten yang ada di dalamnya. Berbagai media online sam televisi nasional kemudian menindaklanjuti perbincangan ini dengan Public Relations (PR) Value yang sangat besar bila dihitung secara materi.

Hal ini tentunya tidak terjadi begitu saja. Oleh karenanya artikel jurnal ini coba mengupas secara konten dan juga strategi digital sehingga film Tilik mampu memperoleh paparan seperti disebutkan.

\section{METODE PENELITIAN}

\section{Analisis Konten}

Objek penelitian merupakan sebuah media film, oleh karenanya menonton menjadi aktivitas utama. Film sebagai teks kemudian dibaca ulang juga oleh banyak pihak usai film ini selesai mereka tonton meliputi gaya narasi penceritaan, struktur bahasa, dan perlakuan visual dalam film.

Film sebagai sebuah teks dapat dibaca melalui konten, konsep, dan juga tidak bisa dilepaskan dari konteksnya. Konten, konsep dan konteks dari Tilik berperan besar menghasilkan berbagai perbenturan atau dialektika yang menghasilkan di ruang media sosial.

\section{Pengamatan}

Pengamatan dilakukan melalui media sosial dari sebelum film ini resmi diunggah ke platform Youtube 17 Agustus 2020. Atas kepegiatan sehari-hari, penulis sendiri sudah lazim mengikuti berita-berita seputar perfilman dan juga mengikuti beberapa akun film baik akun perorangan ataupun akun kolektif.

Melalui amatan ini dapat dilihat aktivitas beberapa akun Key opinion Leader (KoL) yang berkomentar seputar Tilik dan menginformasikan kapan film ini akan mulai tayang. Usai film diunggah juga dapat dilihat berkembangnya opini terhadap Tilik, akun- akun yang memiliki pengaruh dan menyuarakan pendapatnya dan bagaimana pendapat yang disuarakan ini mempengaruhi lainnya.

Atas dinamika yang berkembang pesat dengan opini yang terus bergulir dan di ruang publk pada masa menuju akhir pekan, pengamatan hanya meliputi sampai hari Sabtu 22 Agustus 2020.

\section{Diskusi Pemerhati dan Praktisi}

Wawancara dilakukan untuk menggali dan memastikan berbagai hal yang menjadi tesis dari penyusun. Dalam menggali info serta pendapat, dilakukan kontak langsung dengan pihak publisis via aplikasi WhatsApp dengan beberapa pertanyaan. Sedangkan untuk menggali pendapat dari pegiat perfilman di komunitas dilakukan dengan melempar materi tautan film sambil melihat bagaimana pendapat yang bersangkutan mengenai fenomena akan film ini.

Selama masa penyusunan artikel jurnal, penyusun ikut terlibat dalam diskusi seputar fenomena film Tilik yang diadakan pada hari Minggu pukul 20.00 sampai 22.00 (Gambar 1). Diskusi daring diikuti oleh para akademisi dan juga pegiat perfilman dengan beragam perspektif sesuai fokus perhatian dan bidang masing-masing. Beberapa poin menarik dari diskusi ini turut diikutkan sebagai penambah wawasan dalam penyusunan jurnal.

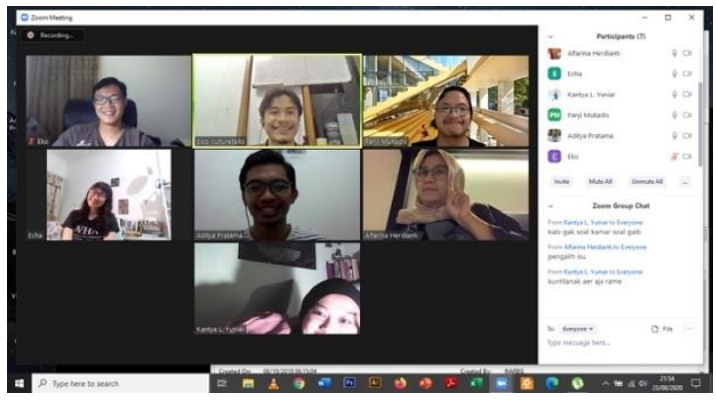

Gambar 1. Kegiatan Diskusi Bersama Akademisi dan Pegiat Film (Sumber : Dokumentasi Pribadi) 


\section{HASIL DAN PEMBAHASAN}

\section{YouTube Sebagai Kanal Distribusi}

Dipilihnya platform YouTube di antara platform video lain merupakan pilihan yang tepat. Dengan reputasi dan lamanya YouTube bercokol, ia telah lama dikenal oleh masyarakat Indonesia untuk menikmati konten video, termasuk film pendek. Kuatnya pengaruh video-video yang diunggah pada YouTube juga dipertegas pada berbagai penelitian, salah satunya melalui penelitian iklan Grab Official (Sasongko, 2018).

Lekatnya YouTube sebagai platform yang dibuka sehari-hari menjadikan hambatan penonton untuk membuka konten yang terunggah di dalamnya jadi lebih sedikit. Sedikit bisa kita samakan ini dengan barrier berkontak menggunakan WhatsApp dibandingkan dulu menggunakan Yahoo Messanger yang harus melalui beberapa proses terlebih dahulu untuk masuk dan tersambung dengan yang lain.

\section{Film Tilik Sebagai Konten Digital}

Selain kanal distribusi, dalam bauran pemasaran produk adalah bagian dari pemasaraan itu sendiri (Kotler). Artinya halhal yang melekat padanya merupakan faktor penting yang dapat membuat laku tidaknya sebuah produk serta atribut-atribut yang menempel padanya dapat digunakan untuk materi promosi. Hal ini berlaku dalam konteks pemasaran film, seperti penelitian yang dilakukan terhadap film Nikah Yuk! (Kristianto, 2020) yang menyebutkan bahwa ulasan terhadap film Nikah Yuk! menjadi kekuatan dan juga ancaman terhadap publikasi film.

Ditarik dari konteksnya film Tilik, Tilik merupakan sebuah film pendek dengan Bahasa Jawa yang pada mulanya tidak ditujukan sebagai konten Youtube melainkan ditujukan terlebih dahulu untuk ditayangkan secara luring baik pada berbagai festival film atau pemutaran alternatif. Usai dua tahun film selesai diproduksi, pihak film Tilik mengunggah film ini di Youtube bertepatan juga dengan aktivitas masyarakat yang belum sepenuhnya pulih karena pandemi Covid-19.

Konteks ini penting untuk dilihat karena membuatnya berbeda dengan jenis konten lain di platform ini. Selain itu Tilik juga merupakan film dengan yang dibuat secara memadai dengan dukungan dana dari Pemerintah Daerah Istimewa Yogyakarta. Perihal teknis menjadi hal yang sudah ditangani dengan dana tersebut, selain untuk mengikuti program pendanaan tersebut proyek-proyek telah tersaring terlebih dahulu dengan mempertimbangkan berbagai hal.

Sebagai konten film pendek, ia memiliki durasi yang lebih singkat dibanding film-film yang biasa ditonton di bioskop komersial. Durasinya yang tiga puluh menit membuatnya masih lebih panjang dari banyak film pendek lain. Walau demikian konten dengan durasi lebih panjang juga sudah mulai banyak diperkenalkan di berbagai platform sehingga mereka yang telah melek beragam konten audio visual -dan kemudian memengaruhi yang lain, telah terbiasa dengan durasi seperti ini.

Menurut Ulin Nuha pelaku perfilman di Kendal, Jawa Tengah, melejitnya film Tilik juga didukung dengan pandemic Korona yang membuat masyarakat haus akan tontonan karena belum bisa pergi ke bioskop. Hal yang masuk akal karena ditarik dari durasi film Tilik dan melihat hari-hari di mana film ini terus ramai diperbincangkan dari Selasa (18/8) hingga Jumat (21/8). Akan lebih sulit membuat orang menonton konten audio visual selama 30 menit sekaligus terus menerus membicarakannya hari kerja kondisi normal. Sebelumnya film Tilik juga telah tayang di TV nasional dan dapat diakses melalui aplikasi, namun tidak menghasilkan perbincangan dengan kuantitas serupa.

Sikap atau pilihan sutradara akan alur termasuk bagaimana Tilik diakhiri menjadi diskusi aspek lain bagaimana perbincangan terus berdengung. Selain perbincangan mengenai beberapa karakter muncul pula kritik terhadap bagaimana film diakhiri. Kritik ini muncul baik dari pegiat perfilman maupun masyarakat luas yang turut menonton film 
Tilik. Mereka saling melempar argumen masing-masing baik saling balas menamggapi atau beropini secara lepas namun dalam konteks menanggapi pendapat orang lain baik setuju atau pun tidak setuju.

Contohnya saja Hikmat Darmawan seorang kritikus dan Ketua Komite Film Dewan Kesenian Jakarta turut menyampaikan pendapatnya tentang Tilik. Hikmat memuji aspek teknis seperti sinematografi, kualitas akting, maupun otentisitas film. Di sisi lain ia mengkritisi penguatan stigma terhadap domain ibu-ibu dan gadis muda yang tergambar dalam film. Pendapat ini ia lontarkan pada berbagai platform baik Twitter, Facebook, dan menuliskan artikel pada sebuah media daring yang membuat dengung terhadap Tilik semakin kuat, belum ditambah dengan tanggapan akan uraiannya di berbagai platform tadi yang kemudian terus menambah kontribusi pada penonton baru. Gambar 2 memperlihatkan penonton baru yang tertarik menonton setelah melihat kritik atas film Tilik yang mana kebetulan merupakan seorang sineas dengan jumlah pengikut signifikan di media sosial.

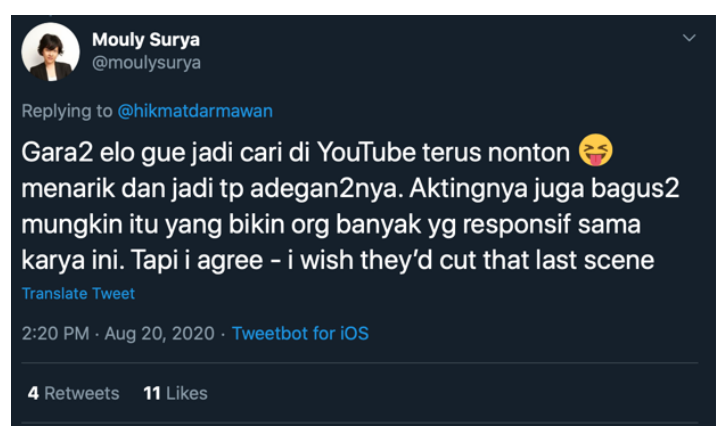

Gambar 2. Penonton Baru Setelah Melihat Kritik (Sumber : Dokumentasi Pribadi)

Dari paragraf di atas dapat disimpulkan bahwa pro dan kontra terhadap film Tilik menjadi salah satu faktor menggelembungnya film. Beberapa hari usai diluncurkan, Ismail Fahmi praktisi analisis media dan pendiri dari Drone Emprit and Media Kernels Indonesia, sebuah sempat membagikan hasil analisis dari viralnya Tilik di media sosial. Dalam hasil analisis tersebut salah satunya terlihat nama-nama memicu mulai ramainya perbincangan seputar Tilik, beberapa di antaranya sosok-sosok yang mengkritik isi dari film Tilik.

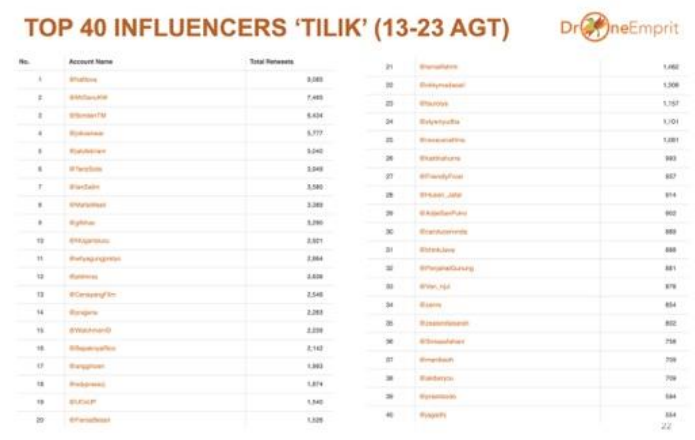

\section{Gambar 3. Empat Puluh Teratas Influencers Film Tilik di Twitter}

Sumber : Drone Emprit (2020)

Walau demikian, konteks awal, tujuan ke mana film ini akan diedarkan, yang mana ditujukan pada pemutaran-pemutaran menjadi penting untuk dilihat kembali. Karena upaya untuk meniru kesuksesaan film Tilik dengan mendahulukan kontroversi akan sulit mendapatkan hasil serupa. Ini diperkuat dari reaksi awal hari pertama film ini diunggah yang mana telah menghasilkan 30.000 views dan sedikit dislike dalam Youtube.

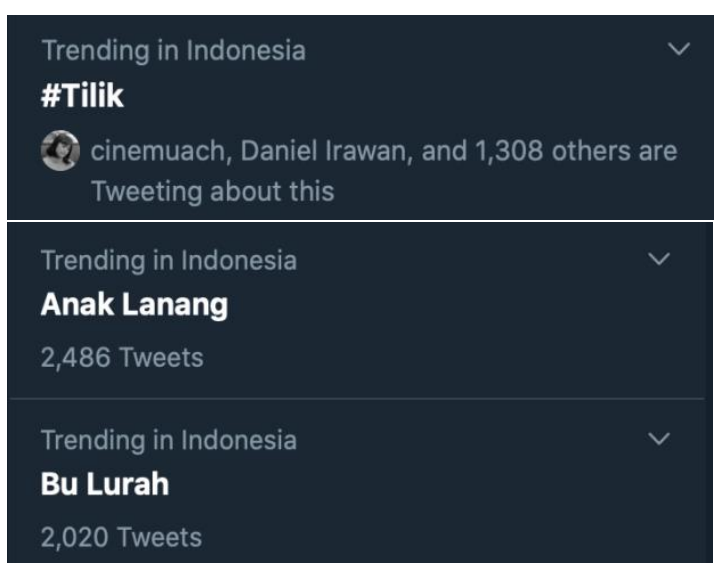

Gambar 4. Kata-kata yang terkait dengan

film Tilik menjadi Trending atau ramai disebut selama beberapa hari (Sumber : Dokumentasi Pribadi)

\section{Strategi Publikasi}

Seminggu sebelum diluncurkannya film Tilik, media yang dikelola oleh penyusun dihubungi untuk diminta menginformasikan terkait akan diunggahnya film Tilik ke Youtube. Hal ini juga dilakukan ke berbagai 
media dan akun perorangan yang sering berbagi tentang perfilman.

Ditanyai mengenai ini, Alfianis biasa dipanggil Vanis selaku publisis dari Ravacana Films menjelaskan bahwa penanganan publikasi dari film Tilik didasari semangat komunitas dan kolektivitas. Sebelum diluncurkannya film Tilik, pihak publisis menghubungi terlebih dahulu beberapa pihak yang dirasa peduli dan memiliki ketertarikan terhadap film pendek.

Saat ditanyai langsung Vanis tidak merinci akun apa saja yang dihubungi pihak Ravacana Pictures, hanya menjelaskan bahwa ada kira-kira 17 akun yang dihubungi dan 10 di antaranya merespon. Dalam wawancara dalam Youtube Asumsi Vanis sempat menyebutkan akun-akun yang dimaksud antara lain Firda (@cinemuach), Paskal (@sinekdoks), @WatchmenID, @infoscreening, Gilang Baskara, Taufik (@TarizSolis), Ali (@alimaruv), Hary Susanto (@hafilova), Muchtar (@achmadmuchtar), @ cinemalinea. Mereka kemudian diberi akses menonton untuk selanjutnya membuat ulasan pada kanal media sosial masing-masing dan menginformasikan kapan film akan terunggah. Saat film terunggah di Youtube, beberapa akun kembali menginformasikan bahwa Tilik telah diunggah di Youtube.

Pendekatan yang dilakukan oleh tim publikasi Tilik bisa digolongkan dalam strategi Public Relations yang metodenya yaitu dengan menggunakan pihak ketiga yang kredibel untuk memberi ulasan dan menginformasikan pada masing-masing audiens. Metode ini telah beberapa kali dilakukan oleh tim Ravacana dalam kondisi lain, misalnya saat film mereka diapresiasi dalam berbagai ajang.

Vanis menjelaskan bahwa sebelum publikasi dijalankan tim terlebih dahulu mengupas apa saja unsur dalam film Tilik. Unsur-unsur inilah yang kemudian dijadikan materi publikasi, dikomunikasikan dilempar dan dibagi pada dua segmen yang berbeda baik untuk penonton festival film, maupun penonton yang lebih umum.
Melalui pemaparan Vanis dapat disimpulkan Tilik telah secara langsung menerapkan formula "segmentation, targeting, positioning (STP) yang menurut Kotler merupakan hal yang esensial dalam strategi pemasaran. Strategi ini penting disiapkan agar Tilik bisa memperoleh perhatian dan dinikmati oleh kedua segmen tersebut, mengingat Tilik tadinya merupakan film yang ditujukan untuk khalayak festival dan baru hendak dibawa ke publik melalui kanal Youtube.

\section{SIMPULAN}

Pertama, dari segi kualitas konten, Tilik memiliki kualitas yang memadai sebagai sebuah film sehingga menghasilkan perbincangan bagi orang yang menontonnya. Tanpa dasar yang baik seperti penyutradaraan, komedi yang kena pada penonton, teknis, maupun kualitas akting akan sulit membangun ketertarikan menonton di awal-awal film diunggah lebih lagi mengharapkan diskusi lanjutan yang ramai terjadi terkait pilihan alur cerita.

Kedua, film Tilik memiliki strategi digital yang cukup untuk menjadikan banyak orang menonton. Usai berkeliling di berbagai pemutaran tim produksi Ravacana Films menggunggahnya di Youtube, sebuah platform raksasa milik Google yang telah familier bagi banyak netizen di Indonesia yang kemudian menonton dan kemudian mendiskusikannya.

Dua tahun film ini berkeliling di pemutaran-pemutaran dan juga nama Wahyu Agung Presetyo dengan film-filmnya terdahulu yang telah mendapat penghargaan merupakan bekal yang tidak sedikit untuk menambah atribut pada produk, dalam hal ini Tilik. Bekal tersebut meninggalkan resonansi awal bagi pihak-pihak yang relevan. Ditambah juga dengan strategi Public Relations dengan terlebih dahulu berkonsolodasi dengan key opinion leader di media sosial untuk terlebih dahulu menonton dan membagikan opini mereka.

Pemilihan Key Opinion Leaders dan arahan materinya telah disiapkan didasari dengan marketing strategi yang cermat sesuai 
dengan formula STP yaitu pertama membagibagi segmen penonton yaitu segmen penonton, menentukan target segmen yang disasar, dan memposisikan Tilik agar dapat diterima oleh segmen yang ditentukan.

Ketiga yaitu pandemi Covid-19 menjadi pendorong bagaimana masyarakat mencari hiburan di tengah terbatasnya akses tempat hiburan terutama seperti bioskop.

Kontroversi seputar berbagai pilihan dari pembuat film turut memberi kontribusi signifikan pada quantitas perbincangan dan ketertarikan untuk menonton, walau demikian menarik konteks tujuan awal film, kontroversi bukan hal yang awalnya direncanakan oleh pembuat film. Usaha untuk mereplikasi kesuksesan Tilik dengan mengedepankan kontroversi akan sulit memberikan hasil serupa. Karena pada dasar atau pada akhirnya produk dan kualitasnyalah yang akan bicara untuk dirinya sendiri (Knight, 313).

\section{DAFTAR PUSTAKA}

\section{Adrian Jonathan Bercerita Soal Kritik Film |} Siasat Sinema. (2020). Retrieved 22 August 2020, from https://www.youtube.com/watch?v=2Q1 LecwUmjQ\&t=209s.

Banjaransari, T, (2016), POSISI FILM ALTERNATIF DI INDONESIA Studi Kontekstualisasi, Penciptaan dan Pengkajian Seni, Institut Seni Indonesia Surakarta, Surakarta

Daniar, A., Marta, R., \& Sampurna, A. (2020). DEFINING BRAND IDENTITY OF NOESA WOVEN FABRIC THROUGH TOTAL BRANDING IN ONLINE MEDIA. Diakom : Jurnal Media Dan Komunikasi, 3(1), 77-88.

Darmawan, H. (2020, Agustus 21) Film Tilik dan Titik Buta Stereotipe - Alif.ID: https://alif.id/read/hd/film-tilik-dan-titikbuta-stereotipe-b232201p/

Imanjaya, E. \& Darmawan, H. (2019). Tilas Kritik: Kumpulan Tulisan Rumah Film 2007-2012. Dewan Kesenian Jakarta
KNIGHT, P. H. (2016). Shoe dog: a memoir by the creator of Nike.

Kotler, P., Keller, K., Ang, S., Tan, C., \& Leong, S. (2018). Marketing management. Pearson.

Monaco, J. (2000). How to read a film. Harbor Electronic Publ.

Mukadis., P, Aviany., I \& Winata., F (2014) Pliage, Pelopor Spesialis Flatshoes Lipat Wanita Buatan Indonesia. Masters thesis, BINUS.

Patel, T. (2016, January 19). The Role and Influence of Social Media on the Modern PR Industry. Retrieved from http://www.prmention.com/blog/the-roleand-influence-of-social-media-onthemodern-pr-industry/

Ravacana Films, Dinas Kebudayaan Yogyakarta. (2018). Tilik[Film]. Yogyakarta.

Ries, A., \& Ries, L. (2006). The fall of advertising and the rise of $P R$. HarperBusiness.

Safitri, Y., \& Ramadanty, S. (2019), Strategi Kampanye Public Relations melalui Peran Key Opinion Leader di Indonesia, Marketing Communication Program, Communication Department, Faculty of Economics and Communication, Bina Nusantara University, Jakarta

Sampurna, A., Tandian, M., Huang, V., Florescia Simanjuntak, R., \& Marta, R. F. (2020). Implementasi Total Branding dalam Perspektif Semiotika Pemasaran . CoverAge: Journal of Strategic Communication, 10(2), 59-73.

Santoso, P (2020) STRATEGI PUBLISITAS DAN PROMOSI FILM NIKAH YUK!, Program Studi Produksi Film dan Televisi. Universitas Dian Nuswantoro, Semarang

Sasongko, Yohanes., Probo, D., \& Marta, R.F. (2018). Ekspresi Identitas Melalui Relasi Ayah dan Anak Pada Iklan Youtube Grab Official. Diakom : Jurnal Media Dan Komunikasi 